DOI: https://doi.org/10.47405/mjssh.v5i12.581

\begin{tabular}{|c|c|}
\hline The & Malaysian Journal of Social Sciences and Humanities (MJSSH) \\
\hline Malaysian Journal of & Volume 5, Issue 12, December 2020 \\
\hline (MJ-ssH) & e-ISSN : 2504-8562 \\
\hline & $\begin{array}{l}\text { Journal home page: } \\
\text { www.msocialsciences.com }\end{array}$ \\
\hline
\end{tabular}

\title{
Sorotan Literatur Bersistematik: Aktiviti Pemikiran Komputasional dalam Pendidikan di Malaysia
}

\author{
Rusno Mohd Kusnan ${ }^{1}$,Nor Habibah Tarmujï ${ }^{2}$, Muhd Khaizer Omar ${ }^{1}$ \\ ${ }^{1}$ Fakulti Pengajian Pendidikan, Universiti Putra Malaysia (UPM) \\ ${ }^{2}$ Fakulti Sains Komputer dan Matematik, Universiti Teknologi MARA (UiTM) \\ Correspondence: Rusno Mohd Kusnan (gs56346@student.upm.edu.my)
}

\begin{abstract}
Abstrak
Kajian semasa bertujuan untuk mengenal pasti jenis aktiviti pemikiran komputasional yang digunakan dalam pendidikan di Malaysia. Metodologi kajian berdasarkan pernyataan PRISMA (Preferred Reporting Items for Systematic reviews and Meta-Analyses) digunakan untuk kaedah tinjauan yang menggunakan pangkalan data utama iaitu Scopus dan Web of Science. Pencarian menyeluruh dalam pangkalan data elektronik terungkap 19 kajian mengenai pemikiran komputasional yang diterbitkan antara Jan 2010 hingga Julai 2020 di Malaysia berdasarkan kriteria-kriteria yang telah ditetapkan. Tinjauan terhadap artikel-artikel ini menunjukkan terdapat 19 aktiviti pemikiran komputasional yang dilakukan dalam konteks kajian di Malaysia. Aktiviti pengaturcaraan (programming) dikenal pasti sebagai aktiviti yang banyak dilakukan berbanding aktiviti robotik, LED (light emitting diode), gamifikasi, kad bergambar haiwan, modul pengajaran, amalan pembelajaran dan pengajaran, serta soal selidik. Manakala, tahap pendidikan yang mengintegrasikan pemikiran komputasional pula secara umumnya merangkumi golongan pelajar pra sekolah, pelajar sekolah rendah, pelajar sekolah menengah, pelajar universiti, guru, pensyarah, warga media sosial, dan warga emas. Kajian-kajian ini disintesis bergantung pada sebilangan ciri umum, seperti bagaimana mereka melakukan aktiviti pemikiran komputasional, tahap pendidikan, dan potensi sumbangan pemikiran komputasional khususnya kepada pelajar. Beberapa cadangan masa depan untuk sarjana diberikan pada akhir kajian ini.
\end{abstract}

Kata kunci: pemikiran komputasional, Malaysia, kajian literatur bersistematik, aktiviti

\section{Systematic Literature Review : Computational Thinking Activities used in the study in Malaysia}

\begin{abstract}
The current study aims to identify the types of computational thinking activities used in the study in Malaysia. The research methodology based on PRISMA statements (Preferred Reporting Items for Systematic reviews and Meta-Analyses) is used for survey methods that use the main database, namely Scopus and Web of Science. A comprehensive search in the electronic database revealed 19 studies on computational thinking published between Jan 2010 to July 2020 in Malaysia based on the criteria that have been set. A review of these articles shows that there are 19 computational thinking activities conducted in the context of research in Malaysia. Programming activities are identified as activities that are done more than robotics, LED (light emitting diode), gamification, animal picture cards, teaching modules, learning and teaching practices, and questionnaires. Meanwhile, the level of
\end{abstract}


education that integrates computational thinking generally includes pre-school students, primary school students, secondary school students, university students, teachers, lecturers, social media citizens, and senior citizens. These studies are synthesized depending on a number of general characteristics, such as how they perform computational thinking activities, the level of education, and the potential contribution of computational thinking in particular to students. Some future suggestions for scholars are given at the end of this study.

Keywords: computational thinking, Malaysia, systematic literature review, activity

\section{Pengenalan}

Pemikiran digital dikatakan sebagai pendekatan berkonsepkan asas dunia pengkomputeran yang melibatkan tiga aspek penting untuk mengatasi masalah dunia nyata, iaitu (1) mengenal pasti masalah, (2) merancang sistem yang dapat digunakan oleh masyarakat, dan (3) memahami tingkah laku manusia (Kumar et al., 2020), ciri-ciri pemikiran digital ini juga mempunyai persamaan dengan kemahiran abad ke-21 iaitu pemikiran kritis, pemikiran inovatif, menitikberatkan penyelesaian masalah, serta kemampuan dalam membuat keputusan (Osman \& Basar, 2016). Paradigma pemikiran digital ini dan corak kemahiran abad ke-21 telah mewujudkan prasyarat baharu dalam pendidikan revolusi industri 4.0 (IR 4.0) iaitu Pemikiran Komputasional. Pemikiran Komputasional atau Computational Thinking merupakan antara kemahiran pemikiran abad ke-21 yang penting untuk generasi masa hadapan mendepani cabaran IR 4.0 (Chong et al., 2019) dan sebagai kriteria pekerjaan yang diinginkan untuk IR 4.0 (KPM, 2019) secara tidak langsung merubah landskap dunia pekerjaan moden untuk berjuta-juta pekerja dan syarikat di seluruh dunia secara digital (WEF, 2018). Dijangkakan pada tahun 2025, 85 juta pekerjaan mungkin dipindahkan kerana pertindanan kerja antara manusia dan mesin, sementara 97 juta peranan baru muncul dan lebih disesuaikan dengan pembahagian kerja baru antara manusia, mesin dan algoritma (WEF, 2020). Manakala, sebanyak 47\% pekerjaan yang ada pada masa kini dijangkakan tidak akan wujud lagi dalam tempoh beberapa tahun akan datang kerana 'computerization' (Frey \& Osborne, 2017), dan 7 dari 10 pekerjaan STEM yang mendapat permintaan tinggi adalah melibatkan komputer dan pengaturcaraan (Fayer et al., 2017).

Ini mendorong pengintegrasian pemikiran komputasional ke dalam sistem pendidikan agar pelajar dapat mempelajari dan mengembangkan kemahiran pemikiran komputasional mereka. Perkembangan pengetahuan dan kemahiran pemikiran komputasional pada peringkat awal pelajar, dipercayai dapat membina asas untuk pelajar menerapkan pendekatan penyelesaian masalah yang sistematik dan memupuk kemahiran berfikir yang lebih tinggi (Naughton, 2012; Falloon, 2016). Ini dibuktikan dengan beberapa kajian luar yang mendapati bahawa pemikiran komputasional boleh diterapkan kepada pelajar seawal usia 4 hingga 6 tahun iaitu ketika pra sekolah (Bers, 2010; Kazakoff et al., 2012; Bers et al., 2014; Muñoz-Repiso \& Caballero-González, 2019; Bers, 2020), kepada pelajar sekolah rendah (Yadav et al., 2011; Falloon, 2015; Kafai, 2016; Chalmers, 2018), pelajar sekolah menengah (Yevseyeva \& Towhidnejad, 2012; Curzon, 2013; Towhidnejad et al., 2014; Rode et al., 2015), pelajar universiti (Morreale, Joiner, \& Chang, 2010; García-Peñalvo \& Mendes, 2018), malahan kepada guru (Mannila et al., 2014; Yadav et al., 2014, 2017; Angeli et al., 2016).

Pemikiran komputasional mendorong inisiatif dan inovasi pelajar untuk memperluaskan pemikirannya dalam menyelesaikan masalah, serta sebagai keperluan dalam mengembangkan keupayaan pelajar belajar sepanjang hayat (Sanford \& Naidu, 2016). Aktiviti pemikiran komputasional yang dirancang sering dikaitkan dengan aktiviti pengaturcaraan, pengekodan, dan sains komputer, khususnya apabila Wing (2006) menyatakan bahawa pemikiran komputasional adalah "proses pemikiran yang terlibat dalam merumuskan masalah dan menyatakan penyelesaiannya mengikut cara komputer-manusia atau mesin-mampu menjalankan dengan efektif" (ms. 33). Maka dengan ini memperkenalkan idea pengkomputeran iaitu pemikiran komputasional pada peringkat awal, dapat membantu pelajar mempersiapkan diri untuk menjadi pelopor kepada teknologi dan tenaga kerja yang kompeten pada masa akan datang. Sehubungan dengan itu, Malaysia telah mengambil inisiatif dengan mengintegrasikan pemikiran komputasional ke dalam silibus pendidikan Malaysia pada tahun 2017 
melalui kurikulum baharu, iaitu Kurikulum Standard Sekolah Rendah (KSSR) dan Kurikulum Standard Sekolah Menengah (KSSM) (Abas, 2016) serta menjadi sokongan kepada matapelajaran yang berteraskan pendidikan Science, Technology, Engineering, Mathematics, (STEM) (BPK, semakan 2018).

Oleh kerana pemikiran komputasional telah menjadi topik yang wajib dipelajari dalam silibus pendidikan formal, adalah perlu untuk meneroka sama ada pelaksanaan aktiviti pemikiran komputasional di dalam kelas mempunyai kesan yang signifikan terhadap pemikiran komputasional pelajar di Malaysia. Justeru, kajian ini bertujuan untuk mengenal pasti aktiviti pemikiran komputasional yang dilakukan dalam konteks pelaksanaannya di Malaysia dan tahap pendidikan yang dijadikan kajian. Persoalan kajian yang menjadi panduan kepada kajian ini adalah seperti berikut:

i. Apakah aktiviti pemikiran komputasional yang dilaksanakan di Malaysia?

ii. Apakah tahap pendidikan yang mengintegrasikan pemikiran komputasional di Malaysia?

iii. Apakah bidang pendidikan yang paling umum untuk aplikasi pemikiran komputasional di Malaysia?

\section{Metod Kajian}

Kajian mengenai aktiviti dan tahap pendidikan pemikiran komputasional dianalisis menggunakan kaedah sorotan literatur bersistematik atau dikenali sebagai SLR (systematic literature review). Dalam kajian ini, empat tahap kaedah SLR dilaksanakan iaitu pengenalpastian (identification), saringan (screening), kelayakan (eligibility), dan pemasukan (inclusion) seperti yang dicadangkan oleh Menggist et al. (2019). Pada peringkat pertama, iaitu pengenalan, beberapa kata kunci digunakan untuk mengenal pasti artikel yang relevan untuk kajian ini. Kata kunci utama yang dipilih untuk dimasukkan dalam kajian ini adalah "Computational Thinking", dan "Malaysia". Selain daripada itu, penggunaan istilah alternatif dan sinonim yang digunakan adalah menggunakan Bahasa Melayu iaitu "Pemikiran Komputasi" atau "Pemikiran Komputasional". Perkataan AND dimasukkan ke dalam kata kunci untuk pelbagai penemuan yang lebih luas dan memperluas pencarian ke dalam kajian khusus mengenai pemikiran komputasional dan operator ATAU untuk menampung ejaan alternatif dan sinonim (Aliyu, 2017; Kitchenham, 2004) seperti dalam Jadual 1.

Jadual 1: Rentetan carian

\begin{tabular}{ll}
\hline Database & \\
\hline WoS & TS=(("Comput* thinking" OR "Computational Thinking") AND (Malaysia")) \\
Scopus & TITLE-ABS-KEY (("Comput* thinking” OR “Computational Thinking") \\
& AND ("Malaysia")) \\
\hline
\end{tabular}

Tinjauan dalam kajian ini dilakukan bergantung kepada dua pangkalan data jurnal utama, iaitu Scopus (https://www.scopus.com/home.uri) dan Web of Science (WoS) (https://mjl.clarivate.com/searchresults). Pangkalan data WoS dianggap sebagai pangkalan data yang kukuh, yang terdiri daripada kirakira 250 disiplin ilmu termasuk bidang subjek sains, sains sosial, dan seni dan kemanusiaan dengan lebih dari 34,000 jurnal. Ditubuhkan oleh Clarivate Analytics, ia terdiri daripada lebih dari 118 tahun fail belakang dan 161 juta rekod data. Sebaliknya, Scopus adalah pangkalan data abstrak dan kutipan terbesar dari literatur yang telah disemak dan digunakan oleh lebih daripada 3,000 buah institusi akademik, kerajaan dan korporat di seluruh dunia. Scopus terdiri daripada jurnal ilmiah, buku dan prosiding persidangan yang berkaitan dengan sains sosial, alam sekitar, pertanian, dan biologi. Secara khusus, WoS mengindeks sejumlah 6,342 jurnal yang berkaitan dengan pemikiran komputasional, sementara Scopus mengindeks 4,710 jurnal yang berkaitan dengan kajian pemikiran komputasional. Namun begitu, dalam konteks kajian di Malaysia, WoS hanya menyenaraikan satu artikel yang berkaitan dengan pemikiran komputasional. Scopus pula menyenaraikan 34 artikel penerbitan. Oleh itu, menurut Zhao (2014) dalam tinjauan sistematik penggunaan beberapa pangkalan data akan menghasilkan keputusan yang tepat dan menghasilkan lebih banyak artikel berbanding dengan menggunakan satu pangkalan data untuk meringkaskan hasil dari berbagai bidang kajian penyelidikan 
yang berkaitan. Di samping itu, dapat meningkatkan kemungkinan untuk mendapatkan artikel yang relevan (Younger, 2010).

Kajian ini hanya akan merujuk kepada artikel yang diterbitkan pada tahun 2010 hingga 2020. Usaha ini berjaya mendapatkan sejumlah 34 jurnal dan persidangan yang berkaitan dengan Pemikiran Komputasional. Dalam fasa saringan untuk memilih artikel yang relevan untuk kajian ini, kriteria pengecualian dan kemasukan ditunjukkan dalam Jadual 2 di bawah.

Jadual 2: Kriteria kemasukan dan pengecualian.

\begin{tabular}{|c|c|c|}
\hline Kriteria & Eligibility & Exclusion \\
\hline Jenis Literatur & $\begin{array}{l}\text { Jurnal (artikel penyelidikan), proses } \\
\text { persidangan }\end{array}$ & $\begin{array}{l}\text { Jurnal (tinjauan sistematik), } \\
\text { siri buku, buku, bab dalam } \\
\text { buku, }\end{array}$ \\
\hline Bahasa & Bahasa Melayu dan Bahasa Inggeris & $\begin{array}{l}\text { Selain Bahasa Melayu dan } \\
\text { Bahasa Inggeris }\end{array}$ \\
\hline Jangkamasa & 2010 to 2020 & $<2010$ \\
\hline Indeks & $\begin{array}{l}\text { Indeks Petikan Sains Sosial, Indeks Petikan } \\
\text { Sumber Muncul, Indeks Seni dan } \\
\text { Kemanusiaan, Indeks Petikan Sains } \\
\text { Diperluas (Web of Science) }\end{array}$ & Tiada \\
\hline Digunapakai & $\begin{array}{l}\text { Aktiviti dan bidang terhadap pemikiran } \\
\text { komputasional }\end{array}$ & Tanpa aktiviti atau bidang \\
\hline
\end{tabular}

Langkah pertama dalam memilih artikel kajian adalah dengan mengeluarkan 1 artikel kajian yang sama atau pendua (Duplicate Paper) yang telah dikenal pasti, hanya tinggal 33 artikel kajian. Proses saringan awal (Screening) juga termasuk semua 33 artikel yang dalam Bahasa Inggeris dan Bahasa Melayu sahaja (Language Compatibility). Usaha ini meninggalkan hanya 33 artikel berkaitan yang layak dimasukkan selepas proses saringan awal. Artikel ini kemudiannya diperiksa dengan lebih jauh untuk memeriksa kelayakan artikel untuk dimasukkan. Untuk fasa terakhir kaedah SLR ini adalah memasukkan artikel paling relevan yang mengandungi aktiviti pemikiran komputasional yang sejajar dengan bidang pemikiran komputasional di Malaysia, langkah menyeluruh dilaksanakan dengan lebih terperinci pada baki artikel. Artikel yang berkenaan diteliti lebih terperinci dengan menyaring tajuk dan abstrak untuk mengecilkan dan menghapuskan artikel kajian yang tidak berkaitan dengan aktiviti dan bidang terhadap pemikiran komputasional. Pada tahap ini, artikel-artikel kajian secara longgar serta tidak tertumpu kepada aktiviti dan bidang yang berkait dengan pemikiran komputasional akan disingkirkan, yang menyebabkan pengecualian 14 artikel.

Hasilnya, 19 artikel dipilih untuk mewakili aktiviti dan bidang yang berkait dengan pemikiran komputasional di Malaysia. 19 artikel kajian yang layak dikelaskan mengikut dua kriteria kemasukan. Pertama, artikel kajian yang memberi tumpuan kepada aktiviti-aktiviti yang dijalankan dan digunakan dalam menentukan kemahiran pemikiran komputasional. Kedua, artikel yang membincangkan secara eksplisit tentang bidang yang dikaitkan dengan pengintegrasian pemikiran komputasional. Oleh itu, kajian menyeluruh mengenai dokumen-dokumen ini dijalankan pada langkah seterusnya. Rajah 1 menunjukkan tahap SLR yang digunakan dalam kajian ini. 
Rajah 1: Carta Alir Kajian Literatur Bersistematik (PRISMA)
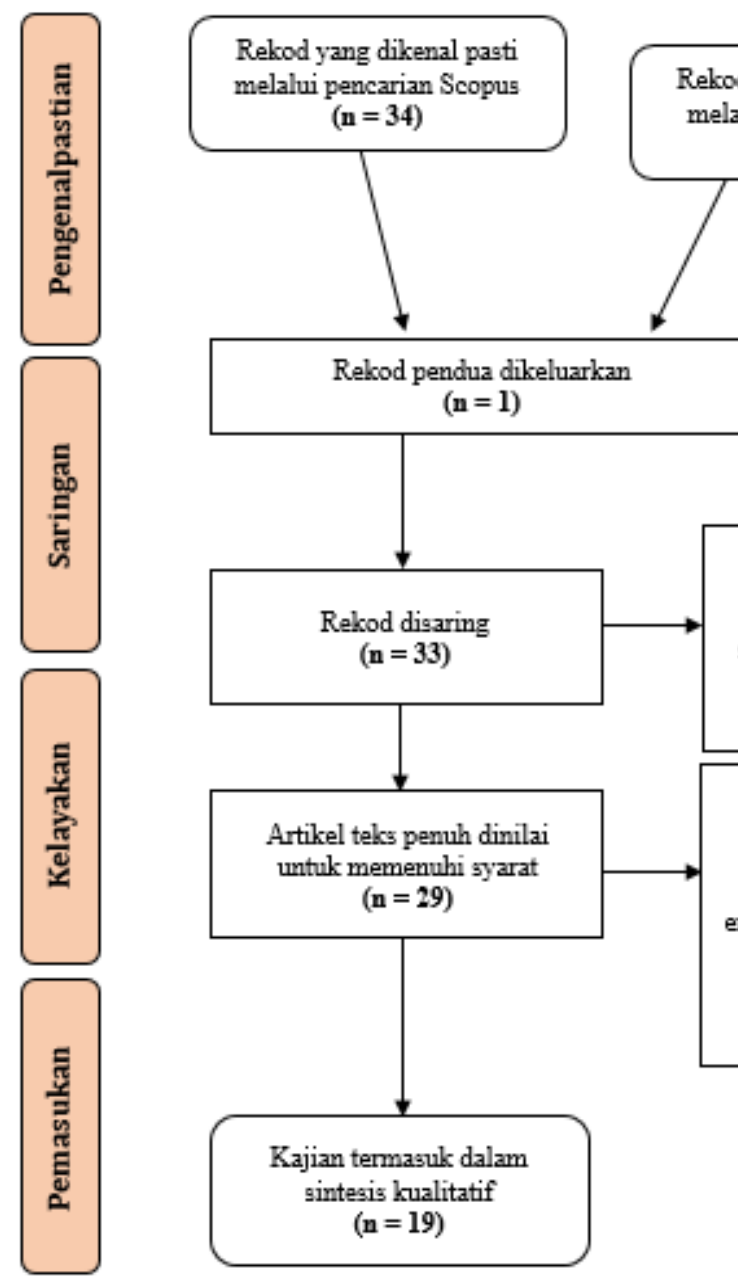

Rekod dikecualikan $(n=4)$

Dikecualikan kerana artikel ulasan sistematik, siri buku, buku, bab buku, Bukan Bahasa Melayu dan Bahasa Inggeris diterbitkan pada $<2010$

Artikel teks penuh dikecualikan, dengan alasan $(\mathrm{n}=10)$

Dikecualikan kerana tidak ada data empirikal atau tidak menumpukan pada artikel empirikal atau tidak menumpukan pada aktiviti CT dan bidang $\mathrm{CT}$. 
Jadual 3: Senarai tahap pendidikan, bidang, dan aktiviti pemikiran komputational di Malaysia

\begin{tabular}{|c|c|c|c|c|c|}
\hline Bil & Penulis Artikel & Tahun & Tahap Pendidikan & Bidang & Aktiviti \\
\hline 1 & Lee \& Ooi & 2020 & $\begin{array}{l}\text { Warga media sosial- } \\
\text { sukarelawan }\end{array}$ & STEM & Pengaturcaraan Python. \\
\hline 2 & Aslina Saad & 2020 & $\begin{array}{l}\text { Murid sekolah rendah - } \\
\text { Tahun } 3 \\
\end{array}$ & STEM & Kad bergambar haiwan. \\
\hline 3 & Asarani \& Yassin & 2020 & Guru & Sains Komputer & Pengaturcaraan dan Robotik \\
\hline 4 & Saari\& Hopkins & 2020 & $\begin{array}{l}\text { Pelajar Universitidan } \\
\text { Guru }\end{array}$ & Alat bantu mengajar & Pengaturcaraan (Fla sh Action Script) \\
\hline 5 & Jack et al. & 2019 & $\begin{array}{l}\text { Pra sekolah }-5 \text { hingga } 6 \\
\text { tahun }\end{array}$ & STEM & Kerangka Pembelajaran Pengaturcaraan \\
\hline 6 & Ubaidullah \& Hamid & 2019 & Tenaga pengajar & Sains Komputer & Portal Penga turcaraan Pembelajaran Berasaskan Web \\
\hline 7 & Ling et al. & 2019 & Guru sekolah rendah & TeknologiMaklumat & Amalan pengajaran dan pembelajaran \\
\hline 8 & Perumalet al. & 2019 & $\begin{array}{c}\text { Murid sekolah menengah- } \\
\text { Tingkatan } 4\end{array}$ & Sains Komputer & Pengaturcaraan menggunakan modul Turtle Graphic-MyJavaSchool \\
\hline 9 & Siti Ra shidahet al. & 2019 & $\begin{array}{c}\text { Pelajar Universiti-tahun } \\
\text { akhir }\end{array}$ & Kejuruteraan Awam & Soal selidik tentang Kemahiran Penting untuk IR 4.0 \\
\hline 10 & Shanmugam \& Nadesan & 2019 & PelajarPrasiswazah & STEM & ModulPembangunan Aplikasi Mudah Alih (M-CT) \\
\hline 11 & Ha slina Hassan et al & 2018 & $\begin{array}{c}\text { Murid sekolah rendah - } \\
\text { Tahun4 } \\
\end{array}$ & Teknologi Maklumat & Pengaturcaraan Scratch \\
\hline 12 & Zaharin et al. & 2018 & Pelajar & $\begin{array}{l}\text { Kemahiran Berfikir Ara s } \\
\text { Tinggi (KBAT) }\end{array}$ & $\begin{array}{l}\text { Permainan interaktif seperti Hopscotch atau Scratch, dan robotik, LED, } \\
\text { rangsangan agen pengekodan }\end{array}$ \\
\hline 13 & Wan Nor Ashiqin & 2018 & Pensyarahuniversiti & $\begin{array}{c}\text { Technical and vocational } \\
\text { education and training } \\
\text { (TVET) }\end{array}$ & Pembelajaran Berasaskan Inkuiri (IBL) dengan pengaturcaraan Scratch \\
\hline 14 & Siong \& Osman & 2018 & Guru STEM & STEM & Pembelajaran Berasaskan Permainan - Permainan Komputer \\
\hline 15 & Felicia et al. & 2017 & Murid sekolah rendah & $\begin{array}{c}\text { PSI-TECH (Inventori } \\
\text { Penyelesaian Masalah } \\
\text { Teknologi) } \\
\end{array}$ & Robotik dan Pengaturcaraan Grafik \\
\hline 16 & Lee \& Wong & 2017 & Warga emas & STEM & Gamifikasi-bingo dan permainan senaman \\
\hline 17 & Saariet al. & 2016 & Guru dan Guru Pelatih & Sains Komputer & Flash Action Script dan alatan Fla sh \\
\hline 18 & Saariet al. & 2015 & Guru dan Pelajar & Alat bantu mengajar & Pera latan pengaturcaraan \\
\hline 19 & Erni Marlina Saari & 2014 & Guru Pelatih & $\begin{array}{c}\text { Bahan Bantu Mengajar } \\
\text { dan Motivasi }\end{array}$ & Pengaturcaraan \\
\hline
\end{tabular}




\section{Dapatan dan Perbincangan}

\section{Aktiviti Pemikiran Komputasional}

Dapatan daripada hasil kajian sorotan literatur bersistematik menunjukkan terdapat 19 kajian yang berjaya dikenal pasti berkaitan dengan aktiviti pemikiran komputasional. Di dalam 19 kajian ini, terdapat lapan jenis aktiviti pemikiran komputasional yang telah dikenal pasti iaitu pengaturcaraan (programming), robotik, LED (light emitting diode), gamifikasi, kad bergambar haiwan, modul pengajaran, amalan pembelajaran dan pengajaran, serta soal selidik. Terdapat 13 kajian yang menunjukkan pengaturcaraan menjadi aktiviti yang sering dikaitkan dengan pemikiran komputasional manakala enam kajian lagi menyatakan aktiviti selain dari pengaturcaraan. Jadual 3 menunjukkan secara jelas lapan jenis aktiviti pemikiran komputasional yang telah dikenal pasti, enam tahap pendidikan dan lapan bidang pendidikan yang umumnya mengaplikasikan pemikiran komputasional.

Kebanyakan aktiviti pemikiran komputasional yang dikaji dalam kajian ini menggunakan pendekatan pengaturcaraan seperti Scratch, Phyton, Flash Action Script, Java, dan Web. Walaupun begitu, terdapat juga pendekatan aktiviti yang lain seperti robotik, kad bergambar haiwan, modul, gamifikasi, permainan komputer, LED, amalan pengajaran dan pembelajaran, dan soal selidik. Berdasarkan analisis hasil kajian dan pemerhatian pada jadual 3, ini menunjukkan bahawa pendekatan pengaturcaraan merupakan aktiviti yang paling banyak diaplikasikan sebagai aktiviti pemikiran komputasional di Malaysia.

\section{Tahap Pendidikan}

Dapatan kajian untuk menjawab persoalan kedua adalah pemikiran komputasional diajar dan diterapkan pada enam tahap pendidikan di Malaysia, iaitu di prasekolah (Jack et al., 2019), sekolah rendah (Aslina, 2020; Ling et al., 2019; Haslina et al., 2018), sekolah menengah (Perumal et al., 2019), institusi pengajian tinggi (Saari et al., 2015; Azlin, 2018; Wan Nor Ashiqin, 2018; Siti Rashidah et al., 2019; Shanmugam \& Nadesan, 2019; Saari \& Hopkins, 2020), warga media sosial (Lee \& Ooi, 2020), dan komuniti warga emas (Lee \& Wong, 2017). Sehubungan dengan itu, pemikiran komputasional sesuai diajar dan diterapkan pada setiap tahap pendidikan di Malaysia, dari seawal usia (pra sekolah) sehingga ke usia emas (warga tua).

\section{Bidang Pendidikan}

Terdapat lapan bidang yang berkaitan dengan bidang pendidikan yang paling umum untuk aplikasi pemikiran komputasional iaitu STEM, Sains Komputer, Teknologi Maklumat, Kejuruteraan Awam, Technical and Vocational Education and Training (TVET), Kemahiran Berfikir Aras Tinggi (KBAT), alat bantu mengajar, dan pengetahuan umum. Dapatan kajian bagi persoalan ketiga ini menunjukkan bahawa pemikiran komputasional sesuai untuk diaplikasi pada setiap bidang pendidikan di Malaysia. Ini kerana, pemikiran komputasional seiring dengan agenda pendidikan negara untuk memperkukuhkan bidang STEM seperti yang digariskan dalam Pelan Pembangunan Pendidikan Malaysia (PPPM) 2013-2025 serta memperkasakan bidang pendidikan TVET dalam memacu pembangunan ekonomi Malaysia ke arah merealisasikan negara yang berprestasi tinggi (Malaysian Qualification Agency, 2016).

\section{Cadangan}

Di Malaysia, pemikiran komputasional adalah sesuatu yang baharu ekoran pengintegrasiannya bermula pada tahun 2017 melalui semakan kurikulum baharu KSSR dan KSSM di dalam mata pelajaran asas sains komputer (ASK) dan sains komputer (SK). Justeru, kesemua aktiviti pengajaran dan pembelajaran pemikiran komputasional di sekolah hanya tertumpu pada mata pelajaran tersebut. Oleh itu, aktiviti pemikiran komputasional di Malaysia tidak hanya tertumpu kepada mata pelajaran ASK atau SK sahaja tetapi perlu diperluas kepada mata pelajaran yang lain, sepertimana kajian-kajian dari luar negara yang mengaplikasikan aktiviti pemikiran komputasional dalam mata pelajaran Sains dan Matematik (Sengupta et al., 2013; Orton et al., 2016; Weintrop et al., 2016), Kimia dan Fizik 
(Tendre and Denning, 2016), Biologi, Ekonomi, Bahasa Inggeris, Seni Bahasa, Seni Visual, Kemanusiaan, dan Sains (Settle et al., 2013), Seni dan Sastera (de Paula et al., 2018).

\section{Kesimpulan}

Kesimpulannya, ulasan kajian literatur bersistematik ini bertujuan untuk menyumbangkan kepada pengetahuan serta mampu memberikan pencerahan melalui analisis artikel tentang aktiviti, tahap pendidikan, dan bidang pendidikan yang umumnya mengintegrasikan pemikiran komputasional di Malaysia. Berdasarkan pencarian literatur, kajian ini relevan memandangkan masih belum banyak kajian literatur bersistematik yang ditemui memfokuskan kepada pemikiran komputasional khususnya pendekatan yang berkesan kepada aktiviti pengajaran dan pembelajaran di dalam bilik darjah.

\section{Rujukan}

Abas, A. (2016). Computational Thinking Skills to be Introduced in School Curriculum Next Year. New Straits Times. https://www.nst.com.my/ news/2016/08/164732/computational-thinkingskills-be-introducedschool-curriculum-next-year.

Aliyu, M.B. (2017). Efficiency of Boolean search strings for Information retrieval. American Journal of Engineering Research, 6(11), 216-222. Retrieved from www.ajer.org

Angeli, C., Voogt, J., Fluck, A., Webb, M., Cox, M., Malyn-Smith, J., \& Zagami, J. (2016). A K-6 computational thinking curriculum framework: Implications for teacher knowledge. Journal of Educational Technology \& Society, 19(3), 47-57.

Bahagian Pembangunan Kurikulum. (2015). Kurikulum Standard Sekolah Menengah (KSSM): Dokumen Standard Kurikulum dan Pentaksiran (DSKP) Sains Komputer Tingkatan Empat. Putrajaya. http://bpk.moe.gov.my/index.php/terbitan-bpk/kurikulum-sekolahmenengah/category/17-dskp-tingkatan-4?download=1090:sains-komputer-tingkatan-4.

Bers, M. U. (2020). Coding as a playground: Programming and computational thinking in the early childhood classroom. Routledge.

Bers, M. U., Flannery, L., Kazakoff, E. R, \& Sullivan, A. (2014). Computational thinking and tinkering: Exploration of an early childhood robotics curriculum. Computers \& Education, 72, 145-157. https://doi.org/10.1016/j.compedu.2013.10.020

Bers, M. U. (2010). The TangibleK Robotics program: Applied computational thinking for young children. Early Childhood Research \& Practice, 12(2). Retrieved from https://eric.ed.gov/?id=EJ910910

Chalmers, C. (2018). Robotics and computational thinking in primary school. International Journal of Child-Computer Interaction, 17, 93-100. https://doi.org/10.1016/j.ijcci.2018.06.005

Chong, B., \& Wong, R. (2019). Transforming the Quality of Workforce in the Textile and Apparel Industry Through Computational Thinking Education. In Computational Thinking Education (pp. 261-275). Springer, Singapore. https://doi.org/10.1007/978-981-13-6528-7_15.

Curzon, P. (2013). Cs4fn and computational thinking unplugged. In ACM International Conference Proceeding Series (pp. 47-50). Association for Computing Machinery. https://doi.org/10.1145/2532748.2611263

de Paula, B. H., Burn, A., Noss, R., \& Valente, J. A. (2018). Playing Beowulf: Bridging computational thinking, arts and literature through game-making. International Journal of Child-Computer Interaction, 16, 39-46. https://doi.org/10.1016/j.ijcci.2017.11.003

Erni Marlina Saari. (2014). Motivation for Trainee Teachers: Non-Computing Background Learn Action Script. In International Journal of Computer and Information Technology, Vol. 3(1), 133$138 . \quad$ Retrieved from https://www.researchgate.net/publication/301219827_Motivation_for_Trainee_Teachers_NonComputing_Background_Learn_Action_Script

Falloon, G. (2016). An analysis of young students' thinking when completing basic coding tasks using Scratch Jnr. On the iPad. Journal of Computer Assisted Learning, 32(6), 576-593. https://doi.org/10.1111/jcal.12155 
Falloon, G. (2015). Building computational thinking through programming in K-6 education: A New Zealand experience. In EDULEARN15 Conference (pp. 882-892). IATED Academy. Retrieved from https://hdl.handle.net/10289/9455

Fayer, S., Lacey, A., \& Watson, A. (2017). STEM Occupations: Past, present, and future. Spotlight on Statistics, US Bureau of Labor Statistics, (January), 1-35. Retrieved from https://www.bls.gov/spotlight/2017/science-technology-engineering-and-mathematics-stemoccupations-past-present-and-future/pdf/science-technology-engineering-and-mathematics-stemoccupations-past-present-and-future.pdf

Felicia, A., Sha'rif, S., Wong, W., \& Mariappan, M. (2017). Computational Thinking and Tinkering: Exploration Study of Primary School Students' in Robotic and Graphical Programming. Asian Journal of Assessment in Teaching and Learning, 7, 44-54. https://doi.org/10.37134/ajatel.vol7.5.2017

Frey, C. B., \& Osborne, M. A. (2017). The future of employment: How susceptible are jobs to computerisation?. Technological forecasting and social change, 114, 254-280. https://doi.org/10.1016/j.techfore.2016.08.019

García-Peñalvo, F. J., \& Mendes, A. J. (2018, March 1). Exploring the computational thinking effects in pre-university education. Computers in Human Behavior. Elsevier Ltd. https://doi.org/10.1016/j.chb.2017.12.005

Hassan, H., Adnan, A., Poh, L. G., \& Hashim, M. S. M. (2018). USING SCRATCH PROGRAMMING TO ENGAGE PRIMARY SCHOOL PUPILS IN COMPUTATIONAL THINKING. Jurnal Penyelidikan Tempawan Jilid XXXV, 49. Retrieved from http://tempawan.ipgkik.edu.my/wp-content/uploads/2019/02/4_2018.pdf

Jack, L. P., Khamis, N., Salimun, C., Nizam, D. M., Haslinda, Z., \& Baharum, A. (2019). Learn programming framework for malaysian preschoolers. International Journal of Advanced Trends in Computer Science and Engineering, 8(1.6 Special Issue), 431-436. https://doi.org/10.30534/ijatcse/2019/6281.62019

Kafai, Y. B. (2016). From computational thinking to computational participation in K--12 education. Communications of the ACM, 59(8), 26-27. https://doi.org/10.1145/2955114

Kazakoff, E. R., Sullivan, A., \& Bers, M. U. (2013). The effect of a classroom-based intensive robotics and programming workshop on sequencing ability in early childhood. Early Childhood Education Journal, 41(4), 245-255. https://doi.org/10.1007/s10643-012-0554-5

Kementerian Pendidikan Malaysia (KPM). (2019). Teks ucapan ucaptama dan majlis perasmian YB Dr. Maszlee Malik menteri pendidikan sempena kolokium pendidikan Revolusi Industri 4.0. Kolokium Pendidikan Revolusi Industri 4.0, 23(3), 6. https://doi.org/10.5281/zenodo.1477753

Kitchenham, B. (2004). Procedures for performing systematic reviews. Keele University, UK and National ICT Australia, 33, 28. https://doi.org/10.1.1.122.3308

Kumar K., Zindani D., and Davim J.P. (2020) Digital Thinking in Education. In: Design Thinking to Digital Thinking. SpringerBriefs in Applied Sciences and Technology. Springer, Cham. https://doi.org/10.1007/978-3-030-31359-3_5

Lee, C. S., \& Ooi, E. H. (2020). Design to Encourage Reframing and Transformations through Digital Story telling and Analogical Thinking. International Journal, 9(1.3). https://doi.org/10.30534/ijatcse/2020/0991.32020

Lee, C. S., \& Wong, K. D. (2017). Developing community-based engagement in smart cities: A design-computational thinking approach. In IEEE International Conference on Industrial Engineering and Engineering Management (Vol. 2017-December, pp. 832-836). IEEE Computer Society. https://doi.org/10.1109/IEEM.2017.8290008

Ling, U. L., Saibin, T. C., Labadin, J., \& Aziz, N. A. (2019). Assessing Malaysian Teachers' Perception on Computational Thinking Concepts Using SEM. In Proceedings of the Third International Conference on Computing, Mathematics and Statistics (iCMS2017) (pp. 513-519). Springer, Singapore. https://doi.org/10.1007/978-981-13-7279-7_64

WEF. (2018). The Future of Jobs Report 2018. In World Economic Development Quarterly (Vol. 31, Issue 2). https://doi.org/10.1177/0891242417690604

WEF. (2020). Schools of the future: Defining new models of education for the fourth industrial revolution. World Economic Forum Reports 2020, January, 1-33. www.weforum.org

Mannila, L., Dagiene, V., Demo, B., Grgurina, N., Mirolo, C., Rolandsson, L., \& Settle, A. (2014). Computational thinking in K-9 education. In ITiCSE-WGR 2014 - Working Group Reports of the 
2014 Innovation and Technology in Computer Science Education Conference (pp. 1-29). Association for Computing Machinery, Inc. https://doi.org/10.1145/2713609.2713610

Menggist, W., Soromessa, T.\& Feyisa, G. L. (2019). Method for Conducting Systematic Literature Review and Meta-Analysis for Environmental Science Research. MethodsX. 100777. https://doi.org/10.1016/j.mex.2019.100777

Mohd Asarani, U., \& Mohd Yassin, S. (2020). PENGINTEGRASIAN PEMIKIRAN KOMPUTASIONAL DALAM AKTIVITI PENGATURCARAAN DAN ROBOTIK. International Journal Of Education And Pedagogy, 2(2), 124-133. Retrieved from http://myjms.mohe.gov.my/index.php/ijeap/article/view/9878

Moher, D., Liberati, A., Tetzlaff, J., Altman, D. G., \& Prisma Group. (2009). Preferred reporting items for systematic reviews and meta-analyses: the PRISMA statement. PLoS med, 6(7), e1000097. https://doi.org/10.1371/journal.pmed.1000097

Morreale, P., Joiner, D., \& Chang, G. (2010). Connecting undergraduate programs to high school students: teacher workshops on computational thinking and computer science. Journal of Computing Sciences in Colleges, 25(6), 191-197.

Muñoz-Repiso, A. G. V., \& Caballero-González, Y. A. (2019). Robotics to develop computational thinking in early Childhood Education. Comunicar, 27(59), 63-72. https://doi.org/10.3916/C592019-06

Malaysia Qualification Agency. (2016). Yearly report 2016. Agensi Kelayakan Malaysia, Selangor.

Orton, K., Weintrop, D., Beheshti, E., Horn, M., Jona, K., \& Wilensky, U. (2016). Bringing computational thinking into high school mathematics and science classrooms. In Proceedings of International Conference of the Learning Sciences, ICLS (Vol. 2, pp. 705-712). International Society of the Learning Sciences (ISLS).

Osman, B. H. A., \& Basar, M. N. (2016). Amalan Pengajaran dan Pembelajaran Abad Ke-21 Dalam Kalangan Pensyarah Institut Pendidikan Guru Kampus Ipoh. Jurnal Penyelidikan Dedikasi. Jilid 10.

Pelan Pembangunan Pendidikan Malaysia 2013-2025. Petikan Ucapan Tan Sri Muhyiddin Yassin Ketika Membentangkan Laporan Awal Pelan Pembangunan Pendidikan Malaysia 2013-2025 Pada 13/9/2012, 1-12. Retrieved from http://www.moe.gov.my/cms/upload_files/articlefile/2013/articlefile_file_003113.pdf

Perumal, A., Latih, R., \& Abu Bakar, M. (2019). MyJavaSchool: Students' Perceptions and Motivation for Computer Programming. Asia-Pacific Journal of Information Technology \& Multimedia, 08(02), 71-78. https://doi.org/10.17576/apjitm-2019-0802-05

Rode, J. A., Weibert, A., Marshall, A., Aal, K., von Rekowski, T., El Mimouni, H., \& Booker, J. (2015, September). From computational thinking to computational making. In Proceedings of the 2015 ACM International Joint Conference on Pervasive and Ubiquitous Computing (pp. 239250). Association for Computing Machinery, Inc. https://doi.org/10.1145/2750858.2804261

Saad, A. (2020). Students' Computational Thinking Skill through Cooperative Learning Based on Hands-on, Inquiry-based, and Student-centric Learning Approaches. Universal Journal of Educational Research, 8(1), 290-296. https://doi.org/10.13189/ujer.2020.080135

Saari, E. M., \& Hopkins, G. (2020). Computational thinking - Essential and pervasive toolset. Asian Journal of Assessment in Teaching and Learning,10(1), 23-30. Retrieved from https://ejournal.upsi.edu.my/index.php/AJATeL/article/view/3182

Saari, E. M., Blanchfield, P., \& Hopkins, G. (2016). Computational thinking: A tool to motivate understanding in elementary school teachers. In Communications in Computer and Information Science (Vol. 583, pp. 348-364). Springer Verlag. https://doi.org/10.1007/978-3-319-29585-5_20

Saari, E. M., Blanchfield, P., \& Hopkins, G. (2015). Learning computational thinking through the use of flash action scripts: Preparing Trainee Elementary School Teachers for Teaching Computer Programming. In CSEDU 2015 - 7th International Conference on Computer Supported $\begin{array}{llll}\text { Education, } & \text { Proceedings (Vol. } & 2, & \text { pp. }\end{array}$ https://doi.org/10.5220/0005442600750084

Sanford, J. F., \& Naidu, J. T. (2016). Computational thinking concepts for grade school. Contemporary Issues in Education Research (CIER), 9(1), 23-32. https://doi.org/10.19030/cier.v9i1.9547

Sengupta, P., Kinnebrew, J. S., Basu, S., Biswas, G., \& Clark, D. (2013). Integrating computational thinking with K-12 science education using agent-based computation: A theoretical 
DOI: https://doi.org/10.47405/mjssh.v5i12.581

framework. Education and Information Technologies, 18(2), 351-380. https://doi.org/10.1007/s10639-012-9240-X

Settle, A., Goldberg, D. S., \& Barr, V. (2013). Beyond computer science: Computational thinking across disciplines. In Annual Conference on Innovation and Technology in Computer Science Education, ITiCSE (pp. 311-312). https://doi.org/10.1145/2462476.2462511

Shanmugam, L., \& Nadesan, G. (2019). An Innovative Module for Learning Computational Thinking Skills among Undergraduate Students. International Journal of Academic Research in Progressive Education and Development, 8(4). https://doi.org/10.6007/ijarped/v8-i4/6440

Siong, W., \& Osman, K. (2018). Pembelajaran Berasaskan Permainan dalam Pendidikan STEM dan Penguasaan Kemahiran Abad Ke-21. Politeknik \& Kolej Komuniti Journal Of Social Sciences And Humanities, 3(1), 121-135. Retrieved from http://myjms.mohe.gov.my/index.php/PMJSSH/article/view/4678

Siti Rashidah, M. N., Humphrey, J. V., \& Anizahyati, A. (2019). Essential Skills for Civil Engineering Graduates Towards Industry Revolution 4.0. In Proceedings of the 2019 IEEE 11th International Conference on Engineering Education, ICEED 2019 (pp. 137-140). Institute of Electrical and Electronics Engineers Inc. https://doi.org/10.1109/ICEED47294.2019.8994951

Tedre, M., \& Denning, P. J. (2016). The long quest for computational thinking. In ACM International Conference Proceeding Series (pp. 120-129). Association for Computing Machinery. https://doi.org/10.1145/2999541.2999542

Towhidnejad, M., Kestler, C., Jafer, S., \& Nicholas, V. (2015). Introducing computational thinking through stealth teaching. In Proceedings - Frontiers in Education Conference, FIE (Vol. 2015February). Institute of Electrical and Electronics Engineers Inc. https://doi.org/10.1109/FIE.2014.7044407

Ubaidullah, N. H., \& Hamid, J. (2019). A web-based learning programming portal: Do instructors need it to enhance novice students' computational thinking skill? International Journal of Innovative Technology and Exploring Engineering, 8(9), 1945-1958. https://doi.org/10.35940/ijitee.i8513.078919

Wan Nor Ashiqin. (2018). Preliminary Study in Emerging Competence Domain: Synergised Computational Thinking (CT) Skills and Brain-Based Learning (BBL) in TVET Curriculums. Journal of Human Development and Communication, 7, 95-104. Retrieved from https://johdec.unimap.edu.my/images/PDF/JOHDEC\%20DIS\%202018/Vol_7_2018_95104.pdf

Weintrop, D., Beheshti, E., Horn, M., Orton, K., Jona, K., Trouille, L., \& Wilensky, U. (2016). Defining Computational Thinking for Mathematics and Science Classrooms. Journal of Science Education and Technology, 25(1), 127-147. https://doi.org/10.1007/s10956-015-9581-5

Wing, J. M. (2006). Computational thinking. Communications of the ACM,49(3), 33-35. https://doi.org/10.1145/1118178.1118215

Yadav, A., Mayfield, C., Zhou, N., Hambrusch, S., \& Korb, J. T. (2014). Computational thinking in elementary and secondary teacher education. ACM Transactions on Computing Education (TOCE), 14(1), 1-16. https://doi.org/10.1145/2576872

Yadav, A., Zhou, N., Mayfield, C., Hambrusch, S., \& Korb, J. T. (2011, March). Introducing computational thinking in education courses. In Proceedings of the 42nd ACM technical symposium on Computer science education (pp. 465-470). https://doi.org/10.1145/1953163.1953297

Yevseyeva, K., \& Towhidnejad, M. (2012). Work in progress: Teaching computational thinking in middle and high school. In Proceedings - Frontiers in Education Conference, FIE. https://doi.org/10.1109/FIE.2012.6462487

Younger, P. (2010). Using Google Scholar to conduct a literature search. Nursing Standard 24 (45): 40-46. https://doi.org/10.7748/ns2010.07.24.45.40.c7906

Zaharin, N. L, Sharif, S., \& Mariappan, M. (2018). Computational Thinking: A Strategy for Developing Problem Solving Skills and Higher Order Thinking Skills (HOTS). Int. J. Acad. Res. Bus. Soc. Sci, 8, 1265-1278. http://dx.doi.org/10.6007/IJ ARBSS/v8-i10/5297

Zhao, J. G. (2014). "Combination of multiple databases is necessary for a valid systematic review." International Orthopaedics 38 (12): 2639-2639. https://doi.org/10.1007/s00264-0142556-y 